\title{
Pengaruh substitusi tepung terigu dengan tepung porang (amorphophallus oncopphyllus) terhadap kadar protein, serat pangan, lemak, dan tingkat penerimaan biskuit
}

\author{
Silmi Mahirdini ${ }^{1}$, Diana Nur Afifah ${ }^{1}$
}

\begin{abstract}
Background : It is associated with a healthy lifestyle in the prevention of cardiovascular disease risk with consumption of lowfat foods and increased consumption of dietary fiber, which can be obtained from porang flour. One of processed food products consumed by many people is a biscuit. This study aims to determine the effect of different substitution of wheat flour with porang flour on protein content, dietary fiber content, fat content, and acceptance level of biscuits.

Methods : Experimental research with a completely randomized design with 4 variations of flour and porang flour substitution each 0: 100\%, 30: 70\%, 60: 40\%, and 100: 0\%. Statistical analysis of protein levels using the Kruskal-Wallis test, while statistical analysis of levels of dietary fiber, and fat using One Way ANOVA 95\% with Tukey test for further analysis. The results of organoleptic test used Friedman test and Wilcoxon test for further analysis.

Results : Highest protein content contained in a biscuit with substitution of $100 \%$ flour porang and $0 \%$ flour, levels of dietary fiber soluble and insoluble highest in substitution of $40 \%$ of porang flour and $60 \%$ wheat flour and fat content was lowest for the biscuits with the substitution of 100\% 0\% porang flour and wheat flour. Based on the results of acceptance level, the closest biscuits are biscuits with a control group of $40 \%$ substitution porang flour and $60 \%$ wheat flour.

Conclusion : Substitution porang flour and wheat flour in making of biscuits to give effect to the levels of soluble dietary fiber and insoluble, fat content, and the level of acceptance.
\end{abstract}

Keyword : protein content, dietary fiber content, fat content, biscuits, wheat flour, porang flour.

\begin{abstract}
ABSTRAK
Latar Belakang : Hal yang berkaitan dengan pola hidup sehat dalam pencegahan risiko penyakit kardiovaskuler yaitu, konsumsi makanan rendah lemak dan peningkatan konsumsi serat pangan, yang dapat diperoleh dari tepung umbi porang. Salah satu produk olahan makanan yang banyak dikonsumsi oleh masyarakat adalah biskuit. Penelitian ini bertujuan untuk mengetahui pengaruh perbedaan substitusi tepung terigu dengan tepung porang terhadap kadar protein, serat pangan, lemak, dan tingkat penerimaan biskuit.

Metode : Penelitian eksperimental dengan rancangan acak lengkap dengan 4 variasi substitusi tepung terigu dan tepung porang masing-masing sebesar 0:100\%, 30:70\%, 60:40\%, dan 100:0\%. Analisis statistik kadar protein menggunakan uji KruskalWallis, sedangkan analisis statistik kadarserat pangan, dan lemak menggunakan uji One Way ANOVA 95\% dengan uji lanjut Tukey. Analisis statistik hasil uji organoleptik menggunakan uji Friedman dengan uji lanjut Wilcoxon.

Hasil : Kadar protein tertinggi terdapat pada biskuit dengan substitusi 100\% tepung porang dan 0\% tepung terigu, kadar serat pangan larut dan tak larut tertinggi terdapat pada substitusi $40 \%$ tepung porang dan $60 \%$ tepung terigu, serta kadar lemak terendah terdapat pada biskuit dengan substitusi 100\% tepung porang dan 0\% tepung terigu. Berdasarkan hasil uji organoleptik, biskuit yang paling mendekati kelompok kontrol adalah biskuit dengan substitusi $40 \%$ tepung porang dan $60 \%$ tepung terigu.

Simpulan : Substitusi tepung porang dan tepung terigu dalam pembuatan biskuit memberikan pengaruh terhadap kadar serat pangan larut dan tak larut, kadar lemak, dan tingkat penerimaan.
\end{abstract}

Kata kunci : kadar protein, kadar serat pangan, kadar lemak, biskuit, tepung porang, tepung terigu.

\section{PENDAHULUAN}

Penyakit kardiovaskular (CVD) masih menjadi penyebab utama kematian di seluruh dunia. ${ }^{1}$ Berdasarkan data World Health Organization (WHO) pada tahun 2012, sebanyak 17,5 juta orang meninggal karena kardiovaskuler dan angka ini akan terus meningkat mencapai 23,3 juta pada tahun 2030. ${ }^{2,3}$ Menurut data Riset Kesehatan Dasar (Riskesdas) 2013

1. Departemen Ilmu Gizi, Fakultas Kedokteran Universitas Diponegoro, Semarang (email korespondensi: d.nurafifah.dna@fk.undip.ac.id) menunjukkan bahwa prevalensi penyakit kardiovaskuler berdasarkan wawancara terdiagnosis di Indonesia sebesar $0,5 \%$ dan berdasarkan terdiagnosis dokter atau gejala sebesar $1,5 \% .{ }^{4}$ Salah satu manifestasi penyakit kardiovaskuler adalah aterosklerosis. Beberapa faktor yang dapat meningkatkan risiko terjadinya aterosklerosis salah satunya yaitu peningkatan kadar kolesterol total dan LDL (Low Density Lipoprotein) darah yang dapat disebabkan oleh peningkatan konsumsi lemak dan kolesterol tinggi dalam makanan. ${ }^{5}$ Salah satu upaya yang dapat dilakukan untuk mencegah dan mengatasi masalah penyakit kardiovaskuler adalah melalui asupan 
makanan yang mengandung rendah lemak dan tinggi serat pangan.

Serat pangan mampu mencegah terjadinya gangguan metabolisme sehingga tubuh terhindar dari kemungkinan serangan penyakit kardiovaskuler. ${ }^{6}$ Serat mampu mengikat asam empedu sehingga mencegah penyerapan kembali dari usus halus dan meningkatkan ekskresinya melalui feses. Hal ini akan meningkatkan konversi kolesterol dari serum darah menjadi asam empedu di dalam hati dengan demikian kolesterol yang beredar dalam darah berkurang. Dalam upaya mengurangi risiko dan menunjang penyembuhan penyakit aterosklerosis dengan pengaturan pola makan yaitu membatasi konsumsi asupan lemak berlebih. ${ }^{7}$ Selain serat pangan dan lemak, protein juga berperan secara langsung terhadap pembentukan citarasa. Protein berperan secara signifikan terhadap sifat fisik bahan pangan melalui kemampuannya membentuk dan menstabilkan gel, busa, dan emulsi. ${ }^{8}$

Biskuit adalah produk kue kering yang dibuat dengan cara memanggang adonan yang terbuat dari tepung terigu atau jenis tepung lainnya dengan atau tanpa substitusinya, minyak atau lemak, dengan atau tanpa penambahan bahan pangan lain dan bahan tambahan pangan yang diizinkan. ${ }^{5}$ Berdasarkan data asosiasi industri, tahun 2012 konsumsi biskuit diperkirakan meningkat 5-8\% didorong oleh kenaikan konsumsi domestik. ${ }^{9}$ Konsumsi biskuit di Indonesia cukup tinggi, hal ini dibuktikan dengan survey yang dilakukan oleh Riset Kesehatan Dasar (RISKESDAS) pada tahun 2013 yang menyatakan bahwa sebanyak $13,40 \%$ penduduk Indonesia mengonsumsi biskuit lebih dari 1 kali per hari, sedangkan konsumsi rata-rata kue kering di Indonesia 0,40 kg/kapita/tahun. ${ }^{10,11}$

Biskuit merupakan jenis makanan ringan yang terbuat dari adonan lunak yang berkadar lemak tinggi. ${ }^{11}$ Tepung porang merupakan salah satu alternatif bahan makanan yang rendah lemak dan tinggi serat. Tepung porang mengandung kadar glukomanan yang cukup tinggi yaitu 64,98\%, kadar serat yang tinggi yaitu 2,5\%, dan kadar lemak yang rendah yaitu $0,02 \%$. Tepung porang adalah polisakarida yang mengandung kalori yang sangat rendah yang sangat baik sebagai sumber serat makanan. Aplikasi penggunaan tepung porang dalam produksi makanan sangat luas karena memberikan banyak manfaat, salah satunya sebagai sumber pangan fungsional. ${ }^{12}$

Berdasarkan latar belakang tersebut, maka salah satu alternatif yang diajukan dalam penelitian ini adalah biskuit dengan substitusi tepung porang. Untuk itu dilakukan penelitian mengenai kadar protein, lemak, serat pangan, dan tingkat penerimaan biskuit dengan substitusi tepung porang.

\section{BAHAN DAN METODE}

Penelitian yang dilakukan adalah penelitian dalam bidang Food Production. Penelitian ini merupakan penelitian eksperimental dengan Rancangan Acak Lengkap (RAL) yang terdiri dari 1 faktor, yaitu kadar substitusi tepung terigu dan tepung porang. Penetapan formulasi didasarkan pada perhitungan estimasi kandungan zat gizi bahan baku pembuatan biskuit yang ditetapkan dengan mempertimbangkan anjuran protein, lemak, dan serat pangan untuk pasien kardiovaskuler. Diperoleh 3 kelompok perlakuan dan 1 kontrol yang disimbolkan dengan $\mathrm{P}_{1}$ (100\% tepung porang), $\mathrm{P}_{2}$ (70\% tepung porang dan $30 \%$ tepung terigu), $\mathrm{P}_{3}(40 \%$ tepung porang dan $60 \%$ tepung terigu), dan $\mathrm{P}_{0}$ (100\% tepung terigu). Tiap kelompok perlakuan dilakukan 3 kali pengulangan yang dianalisis meliputi analisis kadar protein, serat pangan, dan lemak.

Tepung porang berasal dari umbi porang yang dibeli di produsen umbi dan tepung porang di Pacitan, Jawa Timur. Sedangkan tepung terigu yang digunakan tepung terigu dengan protein sedang yang berasal dari toko kue yang ada di Kota Semarang. Prosedur pembuatan biskuit pada penelitian ini meliputi beberapa tahap yaitu pencampuran antara gula dan telur dengan tepung porang dan tepung terigu, kemudian diaduk sampai semua bahan tercampur rata, adonan biskuit dibentuk, atas adonan yang sudah dibentuk diolesi dengan kuning telur, dan dipanggang pada suhu $200^{\circ} \mathrm{C}$ selama 20 menit.

Kadar protein diuji dengan menggunakan metode Bradford, kadar lemak diuji dengan menggunakan metode Soxhlet, dan kadar serat pangan diuji dengan menggunakan metode EnzimatikGravimetrik. Pengujian zat gizi tersebut dilaksanakan di Laboratorium Terpadu Universitas Diponegoro. Hasil analisis kadar protein diolah menggunakan uji statistik Kruskal-Wallis karena data berdistribusi tidak normal, sedangkan serat pangan, dan lemak diolah menggunakan uji statistik One Way ANOVA karena data berdistribusi normal, dan dilanjutkan dengan uji post-hoc Tukey untuk mengetahui beda nyata antar kelompok perlakuan dan kontrol. Kemudian tingkat penerimaan biskuit dengan substitusi tepung terigu dengan tepung porang sebanyak 0:100\%, 30:70\%, 60:40\%, 100:0\% dilakukan pada panelis agak terlatih sebanyak 25 orang mahasiswa Program Studi Ilmu Gizi Universitas Diponegoro meliputi, warna, aroma, tekstur, dan rasa. Hasil tingkat penerimaan dikategorikan menjadi skala 1 sampai 4 , yaitu $1=$ sangat tidak suka, $2=$ tidak suka, $3=$ suka, $4=$ sangat suka. Data tingkat penerimaan diuji statistik dengan menggunakan uji Friedman karena data berdistribusi tidak normal, dilanjutkan dengan uji Wilcoxon untuk mengetahui beda nyata antar kelompok perlakuan dan 
kontrol. Nilai rata-rata yang diperoleh kemudian dikategorikan antara lain $\leq 1,55$ sangat tidak suka, 1,56 - 2,55 tidak suka, 2,56 - 3,55 suka, dan $\geq 3,56$ sangat suka.

Tabel 1. Hasil Analisis Kadar Protein Biskuit dengan Substitusi Tepung Porang dan Tepung Terigu

\begin{tabular}{cc}
\hline Perlakuan & Kadar Protein (\%) \\
\hline $0 \%$ tepung porang $+100 \%$ tepung terigu & $4,43 \pm 4,43^{\mathrm{b}}$ \\
$40 \%$ tepung porang $+60 \%$ tepung terigu & $4,57 \pm 0,63^{\mathrm{a}}$ \\
$70 \%$ tepung porang $+30 \%$ tepung terigu & $4,02 \pm 0,00^{\mathrm{a}}$ \\
$100 \%$ tepung porang $+0 \%$ tepung terigu & $4,98 \pm 0,23^{\mathrm{a}}$ \\
\hline
\end{tabular}

Keterangan: Angka yang diikuti dengan huruf superscript berbeda (a dan b) menunjukkan beda nyata pada kolom yang sama. Tidak ada pengaruh penambahan tepung porang dan tepung terigu terhadap kadar protein.

Kadar protein dalam penelitian ini diukur dengan metode Bradford. Tabel 1 menunjukkan bahwa kadar protein tertinggi terdapat pada biskuit dengan substitusi tepung porang $100 \%$ dan tepung terigu $0 \%$, dimana meningkat $0.55 \%$ dibanding biskuit kontrol. Semakin tinggi kadar substitusi tepung porang, semakin tinggi pula kadar protein yang terkandung dalam biskuit. Hasil uji Kruskal-Wallis menyatakan
HASIL

\section{Kadar Protein \\ Hasil analisis kadar protein biskuit dengan substitusi tepung porang dan tepung terigu dapat dilihat pada Tabel 1.}

Tabel 2. Hasil Analisis Kadar Serat Pangan Larut dan Tak Larut Biskuit dengan Substitusi Tepung Porang dan Tepung Terigu

\begin{tabular}{ccc}
\hline Perlakuan & $\begin{array}{c}\text { Kadar Serat Pangan } \\
\text { Larut (\%) }\end{array}$ & $\begin{array}{c}\text { Kadar Serat Pangan } \\
\text { Tak Larut (\%) }\end{array}$ \\
\hline 0\% tepung porang + 100\% tepung terigu & $0,12 \pm 0,20^{\mathrm{c}}$ & $0,00 \pm 0,05^{\mathrm{b}}$ \\
40\% tepung porang + 60\% tepung terigu & $1,54 \pm 0,18^{\mathrm{a}}$ & $0,52 \pm 0,19^{\mathrm{a}}$ \\
70\% tepung porang + 30\% tepung terigu & $0,99 \pm 0,76^{\mathrm{a}}$ & $0,24 \pm 0,81^{\mathrm{a}}$ \\
$100 \%$ tepung porang $+0 \%$ tepung terigu & $0,69 \pm 0,95^{\mathrm{b}}$ & $0,03 \pm 0,93^{\mathrm{a}}$ \\
\hline & $\mathbf{p = 0 , 0 0 0}$ & $\mathbf{p = 0 , 0 0 0}$ \\
\hline
\end{tabular}

Keterangan: Angka yang diikuti dengan huruf superscript berbeda (a, b, c) menunjukkan beda nyata pada kolom yang sama. Ada pengaruh penambahan tepung porang dan tepung terigu terhadap kadar serat pangan larut.

Kadar serat pangan larut dan tak larut diukur dengan metode Enzimatik-Gravimetrik. Kadar serat pangan larut tertinggi terdapat dalam biskuit dengan substitusi tepung porang $40 \%$ dan tepung terigu $60 \%$, yaitu sebanyak $1,54 \%$, yang meningkat $1,42 \%$ dibanding kontrol. Sedangkan kadar serat pangan tak larut tertinggi terdapat dalam biskuit dengan substitusi tepung porang $40 \%$ dan tepung terigu $60 \%$, yaitu sebanyak $0,52 \%$, yang meningkat $0,31 \%$ dibanding kontrol. Semakin sedikit kadar substitusi tepung porang, semakin tinggi kadar serat pangan larut dan tak larut dalam biskuit. Berdasarkan hasil uji One Way ANOVA, terdapat peningkatan bermakna $(\mathrm{p}=0,000)$ dari substitusi tepung porang dan tepung terigu terhadap kadar serat pangan larut dan tak larut biskuit.

\section{Kadar Lemak}

Hasil analisis kadar lemak biskuit dengan substitusi tepung porang dan tepung terigu dapat dilihat pada Tabel 3.

Pengukuran kadar lemak dilakukan dengan menggunakan metode soxhlet. Kadar lemak tertinggi terdapat dalam biskuit dengan substitusi tepung porang $0 \%$ dan tepung terigu 100\%, yaitu sebanyak $33,30 \%$. Semakin sedikit kadar tepung porang, semakin tinggi kadar lemak dalam biskuit. Berdasarkan hasil uji One Way ANOVA, terdapat peningkatan yang bermakna $(\mathrm{p}=0,000)$ dari substitusi tepung porang dan tepung terigu terhadap kadar lemak biskuit.

\section{Tingkat Penerimaan}

Hasil analisis tingkat penerimaan biskuit dengan substitusi tepung porang dan tepung terigu dapat dilihat pada Tabel 4 . 
Tabel 3. Hasil Analisis Kadar Lemak Biskuit dengan Substitusi Tepung Porang dan Tepung Terigu

\begin{tabular}{cc}
\hline Perlakuan & Kadar Lemak (\%) \\
\hline $0 \%$ tepung porang $+100 \%$ tepung terigu & $33,30 \pm 0,96^{\mathrm{a}}$ \\
$40 \%$ tepung porang $+60 \%$ tepung terigu & $26,94 \pm 1,40^{\mathrm{b}}$ \\
$70 \%$ tepung porang $+30 \%$ tepung terigu & $21,21 \pm 1,45^{\mathrm{c}}$ \\
$100 \%$ tepung porang $+0 \%$ tepung terigu & $15,84 \pm 1,04^{\mathrm{d}}$ \\
\hline
\end{tabular}

Keterangan: Angka yang diikuti dengan huruf superscript berbeda (a, b, c, d) menunjukkan beda nyata pada kolom yang sama. Ada pengaruh penambahan tepung porang dan tepung terigu terhadap kadar lemak.

Tabel 4. Hasil Analisis Tingkat Penerimaan Biskuit dengan Substitusi Tepung Porang dan Tepung Terigu

\begin{tabular}{|c|c|c|c|c|c|}
\hline \multirow{2}{*}{ Perlakuan } & \multicolumn{4}{|c|}{ Kategori } & \multirow[b]{2}{*}{ Rata-rata } \\
\hline & Warna & Aroma & Tekstur & Rasa & \\
\hline $\begin{array}{c}0 \% \text { tepung } \\
\text { porang }+ \\
100 \% \text { tepung } \\
\text { terigu }\end{array}$ & $\begin{array}{c}3,21 \pm 0,52^{\mathrm{a}} \\
(\text { sangat suka) }\end{array}$ & $\begin{array}{c}3,13 \pm 0,48^{a} \\
\text { (sangat suka) }\end{array}$ & $\begin{array}{c}2,93 \pm 0,59^{a} \\
(\text { sangat suka) }\end{array}$ & $\begin{array}{c}3,17 \pm 0,46^{\mathrm{a}} \\
(\text { sangat suka) }\end{array}$ & $\begin{array}{c}3,11 \\
\text { (sangat suka) }\end{array}$ \\
\hline $\begin{array}{l}40 \% \text { tepung } \\
\text { porang }+60 \% \\
\text { tepung terigu }\end{array}$ & $\begin{array}{l}2,45 \pm 0,29^{b} \\
\quad(\text { suka })\end{array}$ & $\begin{array}{l}2,25 \pm 0,58^{b} \\
\quad(\text { suka })\end{array}$ & $\begin{array}{l}1,93 \pm 0,77^{b} \\
\text { (tidak suka) }\end{array}$ & $\begin{array}{l}1,89 \pm 0,96^{b} \\
\text { (tidak suka) }\end{array}$ & $\begin{array}{c}2,13 \\
\text { (suka) }\end{array}$ \\
\hline $\begin{array}{l}70 \% \text { tepung } \\
\text { porang }+30 \% \\
\text { tepung terigu }\end{array}$ & $\begin{array}{c}2,13 \pm 0,63^{b} \\
\quad(\text { suka })\end{array}$ & $\begin{array}{l}1,89 \pm 0,65^{b} \\
\text { (tidak suka) }\end{array}$ & $\begin{array}{l}1,85 \pm 0,70^{\mathrm{b}} \\
\text { (tidak suka) }\end{array}$ & $\begin{array}{c}2,33 \pm 0,53^{b} \\
\quad(\text { suka })\end{array}$ & $\begin{array}{l}2,05 \\
\text { (suka) }\end{array}$ \\
\hline \multirow[t]{2}{*}{$\begin{array}{l}100 \% \text { tepung } \\
\text { porang }+0 \% \\
\text { tepung terigu }\end{array}$} & $\begin{array}{l}1,73 \pm 0,52^{c} \\
\text { (tidak suka) }\end{array}$ & $\begin{array}{l}2,01 \pm 0,77^{\mathrm{b}} \\
\quad(\text { suka })\end{array}$ & $\begin{array}{l}1,49 \pm 0,73^{b} \\
\text { (tidak suka) }\end{array}$ & $\begin{array}{l}1,77 \pm 0,85^{\mathrm{c}} \\
\text { (tidak suka) }\end{array}$ & $\begin{array}{c}1,75 \\
\text { (tidak suka) }\end{array}$ \\
\hline & $\mathrm{p}=0,000$ & $\mathrm{p}=0,000$ & $\mathrm{p}=0,000$ & $\mathrm{p}=0,000$ & \\
\hline
\end{tabular}

Keterangan: Angka yang diikuti dengan huruf superscript berbeda (a, b, c) menunjukkan beda nyata pada kolom yang sama.

\section{Warna}

Berdasarkan tingkat penerimaan diketahui bahwa warna biskuit dengan nilai rerata tertinggi adalah biskuit tanpa tepung porang. Sedangan nilai rerata terendah dari kategori warna adalah biskuit dengan substitusi tepung porang $100 \%$ dan tepung terigu $0 \%$. Uji statistik menunjukkan adanya beda nyata $(\mathrm{p}=0,000)$ antar kelompok perlakuan.

\section{Aroma}

Aroma biskuit yang paling disukai oleh panelis adalah biskuit tanpa tepung porang. Sedangkan aroma biskuit dengan substitusi tepung porang $70 \%$ dan tepung terigu $30 \%$ paling tidak disukai oleh panelis. Uji statistik menujukkan adanya beda nyata $(p=0,000)$ antar kelompok perlakuan.

\section{Tekstur}

Biskuit tanpa tepung porang adalah kelompok perlakuan yang paling disukai oleh panelis dari kategori tekstur. Kelompok perlakuan berikutnya yang disukai panelis berturut-turut adalah biskuit dengan substitusi tepung porang $40 \%$ dan tepung terigu $60 \%$, substitusi tepung porang $70 \%$ dan tepung terigu $30 \%$, dan yang paling tidak disukai adalah substitusi tepung porang $100 \%$ dan tepung terigu $0 \%$. Berdasarkan uji statistik, terdapat perbedaan bermakna $(\mathrm{p}=0,000)$ antar kelompok perlakuan.
Rasa

Tingkat kesukaan rasa biskuit tanpa tepung porang memiliki nilai rerata tertinggi. Sedangkan nilai rerata terendah terdapat pada biskuit dengan substitusi tepung porang $100 \%$ dan tepung terigu $0 \%$. Berdasarkan tingkat penerimaan, panelis lebih menyukai biskuit dengan substitusi tepung porang $0 \%$ dan tepung terigu $100 \%$ dibandingkan dengan substitusi tepung porang $100 \%$ dan tepung terigu $0 \%$. Terdapat perbedaan yang bermakna $(\mathrm{p}=0,000)$ antar kelompok perlakuan.

\section{PEMBAHASAN}

\section{Kadar Protein}

Berdasarkan hasil penelitian, kadar protein biskuit semakin meningkat. Peningkatan kadar protein disebabkan karena adanya bahan lain yang ditambahkan pada proses pengolahan atau adanya proses fisika, kimia, atau biologi yang belum terukur. ${ }^{13}$ Hal ini tidak sesuai dengan literatur yang menunjukkan bahwa kadar protein tepung porang $(3,42 \%)$ lebih rendah daripada kadar protein tepung terigu $(11,72 \%) .{ }^{14}$

Protein merupakan salah satu zat gizi makro yang tersusun atas monomer-monomer asam amino yang dihubungkan oleh ikatan peptida. Di dalam tubuh, protein disintesis dari asam-asam amino yang berasal 
dari protein makanan maupun dari pemecahan proteinprotein tubuh. Protein memiliki fungsi penting untuk pertumbuhan dan perkembangan, karena berperan dalam pembentukan nukleoprotein, enzim dan hormon, pembentukan antibodi, pembentukan sel-sel baru pada jaringan yang rusak, sebagai pengangkut zat-zat gizi, serta sumber energi. ${ }^{15}$ Bahan pangan sumber protein diantaranya adalah biji-bijian, kacang-kacangan, ikan, daging, dan susu. ${ }^{16}$

Di dalam bahan pangan, protein berperan secara langsung terhadap pembentukan citarasa. Protein berperan sebagai prekursor pembentuk senyawa aroma dan rasa yang terbentuk selama reaksi termal atau reaksi enzimatik pada produksi, pemrosesan, dan penyimpanan makanan. Protein juga berperan secara signifikan terhadap sifat fisik bahan pangan melalui kemampuannya membentuk dan menstabilkan gel, busa, dan emulsi. ${ }^{17}$ Produk biskuit ini sebagai makanan selingan sehingga kebutuhan asupan protein yang dianjurkan adalah sekitar $15 \%$ dari total energi atau sebesar 9,4 g/hari. ${ }^{15}$ Dalam satu keping biskuit (12 g) dengan kandungan protein tertinggi (substitusi $100 \%$ tepung porang dan $0 \%$ tepung terigu) dapat menyumbangkan asupan protein sebesar $0,60 \mathrm{~g}$, sehingga dengan mengonsumsi satu keping biskuit per hari dapat memenuhi asupan protein sebesar 4,6\%.

\section{Kadar Serat Pangan}

Pada penelitian ini digunakan analisis serat pangan dengan menggunakan metode enzimatikgravimetrik. Kadar serat pangan larut dan tak larut tertinggi terdapat pada biskuit dengan substitusi tepung porang $40 \%$ dan tepung terigu $60 \%$. Semakin bertambahnya persentase tepung porang yang disubstitusikan, makan semakin menurun kadar serat pangan larut dan tak larut pada biskuit. Meskipun kadar serat pangan larut dan tak larut terdapat pada persentase substitusi $40 \%$ tepung porang dan $60 \%$ tepung terigu lebih rendah dari syarat kadar serat pangan pada literatur, namun kadar serat pangan larut dan tak larut pada substitusi $40 \%$ tepung porang dan $60 \%$ tepung terigu ini masih lebih tinggi dibandingkan dengan substitusi $0 \%$ tepung porang dan $100 \%$ tepung terigu. ${ }^{18}$

Terjadinya penurunan serat pangan pada biskuit dengan perlakuan disebabkan terlarutnya komponen non serat seperti gula sederhana, asam-asam gula, dan komponen lainnya. Serat pangan mengandung gula seperti glukosa, galaktosa, xilosa, manosa, arabinosa, rhamnosa, dan fukosa, serta asamasam gula seperti manuronat, galakturonat, glukuronat, guluronat, dan asam 4-o-metilglukuronat. Menurut Anderson dan Clydesdale yang dikutip oleh Susi, pemasakan dengan panas dapat mempengaruhi kandungan serat pangan atau mengubah distribusi serat antara fraksi larut air dengan fraksi tidak larut air. ${ }^{19}$
Berdasarkan penelitian, kandungan serat umbi porang tinggi dan tanpa kolesterol karena itu sangat baik untuk kesehatan, terutama untuk diet. Selain itu, mengandung glukomanan yang tinggi. Tepung porang memiliki kandungan serat yang cukup tinggi. Serat makanan telah terbukti dapat menurunkan risiko penyakit jantung, salah satunya yaitu serat yang berasal dari glukomanan yang terdapat pada tepung porang. Ada dua macam serat makanan yaitu serat larut dan serat tak larut. Serat larut dapat menurunkan kadar kolesterol dengan mengikatnya di saluran pencernaan dan membawanya keluar. Sedangkan serat tak larut dapat membantu masalah pencernaan. Penelitian membuktikan bahwa konsumsi tepung porang dosis tinggi dalam makanan tinggi serat selama delapan minggu dapat meningkatkan metabolisme lemak. Selain itu juga terjadi penurunan LDL serat peningkatan HDL. ${ }^{20}$

Glukomanan memiliki sifat sebagai serat yang mampu menyerap air. Serat tersebut dapat mengikat garam empedu di lumen usus. Secara normal lebih dari 95\% garam empedu akan di daur ulang dengan cara diserap oleh darah dan dikembalikan lagi di hati. Serat ini akan menghambat proses daur ulang dan garam empedu akan disekresikan melalui feses, sehingga hanya sedikit garam empedu yang dikembalikan ke hati. Hal ini akan merangsang hati untuk membentuk garam empedu yang baru dan akan mengambil kolesterol dari darah sebagai bahan pembentuk garam empedu. Semakin banyak garam empedu yang dibentuk maka kolesterol yang beredar di dalam darah akan semakin berkurang atau turun. ${ }^{21}$

Kecukupan serat kini dianjurkan semakin tinggi, mengingat banyak manfaat yang menguntungkan untuk kesehatan tubuh, kecukupan asupan untuk serat makanan sebagai acuan untuk menjaga kesehatan saluran pencernaan dan kesehatan lainnya. Produk biskuit ini sebagai makanan selingan sehingga kebutuhan asupan serat pangan yang dianjurkan adalah sebesar 3,5 g/hari. ${ }^{15}$ Berdasarkan hasil penelitian, kandungan serat pangan larut dalam satu keping biskuit berkisar $0,72 \%$ atau $0,18 \mathrm{~g} / \mathrm{keping}$.

\section{Kadar Lemak}

Substitusi tepung porang dan tepung terigu berpengaruh signifikan menurunkan kadar lemak biskuit. Hasil analisis kadar lemak menujukkan bahwa jumlah kadar lemak tertinggi terdapat pada perlakuan substitusi $0 \%$ tepung porang dan $100 \%$ tepung terigu, yaitu sebesar 33,30\%, yang meningkat 2 kali lipat dibandingkan biskuit dengan substitusi $100 \%$ tepung porang dan $0 \%$ tepung terigu. Tabel 3 menunjukkan adanya penurunan kadar lemak pada setiap peningkatan jumlah tepung porang yang disubstitusikan dalam biskuit. Hal ini sesuai dengan 
penelitian yang mengatakan bahwa kandungan lemak yang terdapat dalam tepung porang rendah yaitu $0 \%{ }^{22}$

Lemak adalah salah satu komponen makanan multifungsi yang sangat penting untuk kehidupan. Selain memiliki sisi positif, lemak juga mempunyai sisi negatif terhadap kesehatan. Fungsi lemak dalam tubuh antara lain sebagai sumber energi, bagian dari membran sel, mediator aktivitas biologis antar sel, isolator dalam menjaga keseimbangan suhu tubuh, pelindung organ-organ tubuh serta pelarut vitamin A, D, E, dan K. Penambahan lemak dalam makanan memberikan efek rasa lezat dan tekstur makanan menjadi lembut serta gurih. Di dalam tubuh, lemak menghasilkan energi dua kali lebih banyak dibandingkan dengan protein dan karbohidrat. ${ }^{23}$

Penelitian membuktikan bahwa makanan yang mengandung glukomanan dapat memperbaiki profil lipid sehingga dapat dijadikan terapi yang potensial. ${ }^{24}$ Berdasarkan penelitian Bekti, dkk., tepung glukomanan umbi porang (Amorphophallus oncophyllus) mampu menurunkan kadar kolesterol total karena kandungan glukomanan pada umbi tersebut. Glukomanan memiliki sifat sebagai serat yang mampu menyerap air. ${ }^{25}$ Produk biskuit ini sebagai makanan selingan sehingga kebutuhan asupan lemak yang dianjurkan adalah sebesar $7 \mathrm{~g} / \mathrm{hari} .{ }^{15}$ Berdasarkan hasil penelitian, kandungan lemak paling rendah dalam satu keping biskuit (substitusi 100\% tepung porang dan $0 \%$ tepung terigu) dapat menyumbangkan asupan lemak sebesar 1,9 g, sehingga dengan mengonsumsi satu keping biskuit dapat memenuhi asupan lemak sebesar $15,8 \%$.

\section{Tingkat Penerimaan}

Tingkat penerimaan yang diuji meliputi parameter warna, aroma, tekstur, dan rasa biskuit. Tingkat penerimaan biskuit diperoleh dari skor penilaian panelis yang berkisar antara 1-4. Secara keseluruhan biskuit kontrol paling disukai oleh panelis. Sedangkan biskuit yang diberikan perlakuan berupa penambahan tepung porang memiliki nilai rerata 2 yang termasuk kategori tidak suka.

Warna memegang peranan penting dalam menentukan penerimaan panelis karena merupakan kesan pertama yang diperoleh oleh panelis. ${ }^{26}$ Substitusi tepung porang dan tepung terigu memberikan pengaruh yang bermakna terhadap penilaian tingkat penerimaan biskuit. Warna biskuit kontrol adalah warna yang paling disukai oleh panelis yang termasuk kategori sangat suka. Hal ini disebabkan biskuit tanpa adanya substitusi kontrol berwarna kuning cerah, dimana warna kuning dihasilkan oleh kuning telur dan margarin. Sedangkan warna biskuit dengan substitusi tepung porang $100 \%$ dan tepung terigu $0 \%$ memiliki rerata terendah termasuk kategori tidak suka. Menurut panelis biskuit dengan perlakuan berwarna lebih gelap dari biskuit kontrol sehingga warnanya tidak menarik. Warna gelap yang dihasilkan pada biskuit dengan perlakuan dihasilkan oleh tepung porang itu sendiri yang berwarna kuning kecoklatan. Berdasarkan pengukuran derajat keputihan tepung, tepung porang mempunyai nilai derajat keputihan lebih rendah $(46,24 \%)$ daripada tepung terigu $(74,7 \%)$, berati semakin banyak penambahan tepung porang semakin gelap biskuit yang dihasilkan. ${ }^{27,28}$

Aroma atau bau yang menguap merupakan atribut suatu produk yang diterima oleh sel-sel olfaktori yang terdapat di dalam hidung dan diteruskan ke otak dalam bentuk impuls lisrik. Aroma juga ikut menentukan penerimaan sebuah produk. ${ }^{26}$ Berdasarkan hasil uji tingkat penerimaan terhadap aroma biskuit dapat diketahui bahwa tingkat penerimaan panelis terhadap aroma biskuit pada biskuit kontrol memiliki rerata tertinggi dan biskuit dengan substitusi tepung porang $100 \%$ dan tepung terigu $0 \%$ memiliki rerata terendah. Munculnya perbedaan aroma pada biskuit menghasilkan penilaian yang berbeda dari panelis. Hal ini disebabkan karena bahan-bahan yang digunakan dalam pembuatan biskuit yaitu tepung terigu, tepung porang, mentega, telur, dan susu masing-masing mempunyai aroma yang khas. ${ }^{29} \mathrm{Hal}$ ini disebabkan karena tepung porang memiliki aroma yang netral sehingga aroma pada biskuit dengan perlakuan tetap memiliki aroma khas biskuit.

Tekstur merupakan salah satu atribut yang paling penting dalam penerimaan biskuit. ${ }^{26}$ Biskuit kontrol paling disukai oleh panelis dibandingkan dengan kelompok perlakuan lain. Sama seperti aspek warna dan aroma, aspek tekstur biskuit dengan penambahan tepung porang sebesar $100 \%$ tidak disukai oleh panelis. Menurut panelis biskuit dengan perlakuan memiliki tekstur tidak renyah seperti biskuit kontrol. Hal ini dikarenakan tekstur biskuit semakin kasar dengan semakin tingginya substitusi tepung porang karena tepung porang mengandung glukomanan yang merupakan serat makanan yang memiliki ukuran sel lebih besar dibandingkan komponen lain. ${ }^{28}$

Rasa dalam biskuit merupakan kombinasi antara cita rasa dan aroma yang tercipta untuk memenuhi selera panelis. Rasa merupakan persepsi dari indra pengecap yang meliputi rasa asin, manis, asam, dan pahit yang diakibatkan oleh bahan yang terlarut dalam mulut. ${ }^{29}$ Penilaian panelis terhadap biskuit menunjukkan nilai tertinggi diperoleh pada biskuit kontrol, sedangkan nilai terendah diperoleh pada biskuit dengan substitusi tepung porang $100 \%$ dan tepung terigu $0 \%$. Rasa yang dihasilkan dari biskuit dengan perlakuan tidak disukai oleh panelis karena biskuit dengan perlakuan meninggalkan sisa seperti berpasir di dalam mulut.

Tingkat penerimaan biskuit dengan substitusi tepung porang dan tepung terigu kategori aroma, rasa, 
dan warna telah memenuhi syarat yaitu normal berdasarkan SNI syarat mutu biskuit, namun kategori tekstur belum memenuhi syarat karena tekstur biskuit dengan substitusi tepung porang dan tepung terigu tergolong agak kasar. Meskipun demikian, substitusi tepung porang dan tepung terigu pada tekstur biskuit masih bisa diterima oleh konsumen.

\section{SIMPULAN}

Substitusi tepung porang dan tepung terigu dalam pembuatan biskuit memberikan pengaruh terhadap kadar serat pangan larut dan tak larut, kadar lemak, dan tingkat penerimaan. Sedangkan kadar protein pada substitusi tepung porang dan tepung terigu tidak memberikan pengaruh nyata. Tingkat penerimaan yang diuji dengan parameter warna, aroma, tekstur, dan rasa kepada panelis agak terlatih, didapatkan hasil paling mendekati biskuit kontrol adalah biskuit dengan substitusi $40 \%$ tepung porang dan $60 \%$ tepung terigu.

\section{SARAN}

Penelitian selanjutnya mengganti tepung porang dengan tepung glukomanan yang memiliki tekstur tepung lebih halus sehingga dapat meningkatkan penerimaan produk dari segi sensori oleh konsumen. Selain itu, tepung glukomanan memiliki kandungan gizi yang lebih tinggi dibandingkan dengan tepung porang.

\section{UCAPAN TERIMA KASIH}

Puji syukur kepada Allah SWT atas segala berkah yang telah diberikan sehingga karya tulis ilmiah ini dapat diselesaikan. Penulis mengucapkan terima kasih kepada Dr. Diana Nur Afifah, S.TP., M.Si selaku pembimbing dan para penguji atas segala bimbingan dan saran yang telah diberikan dalam penyusunan karya tulis ini. Penulis juga mengucapkan terima kasih kepada orang tua, sahabat, dan teman-teman atas dukungan dan doa, serta kepada pihak-pihak yang telah membantu pelaksanaan penelitian ini yang tidak dapat disebutkan satu per satu.

\section{DAFTAR PUSTAKA}

1. Nichols M., Townsend N., Scarborough P., Rayner M. Cardiovascular Disease in Europe 2014: Epidemiological Update. European Heart Journal doi: 10.1093/eurheartj/ehu299. 2014.

2. World Health Organization (WHO). Cardiovascular diseases (CVDs). 2013. Available from:

http://www.who.int/mediacentre/factsheets/fs317 /en/ [akses 15 Maret 2016].
3. Hardjojo B. Analisis Intervensi Penyuluhan Penyakit Jantung Koroner terhadap Perubahan Tingkat Pengetahuan dan Sikap Pegawai Universitas Terbuka yang Berpotensi Penyakit Jantung Koroner tahun 2011 [Tesis]. Depok: Fakultas Kesehatan Masyarakat Program Studi Keselamatan dan Kesehatan Kerja. 2011.

4. Perhimpunan Dokter Spesialis Kardiovaskular Indonesia. Pedoman Tatalaksana Pencegahan Penyakit Kardiovaskular pada Perempuan. Indonesian Heart Association; 2015.

5. Badan Standardisasi Nasional. SNI 01-2973: Mutu dan Cara Uji Biskuit. Jakarta: BSN. 2011.

6. Rolfes S.R., Pinna K.,Whitney E. Understanding normal and clinical nutrition. 7 th ed. USA: Thomson Laerning; 2006.

7. Hera N. Pola Makan Bergizi Seimbang untuk Penyakit Jantung. Subdit Bina Gizi Klinik Direktorat Bina Gizi Masyarakat Depkes; 2010.

8. Belitz H.D., Grosch W., Schieberle P. Food Chemistry. $3^{\text {rd }}$ ed. Berlin: Spinger-Verlag, p.410412; 2004.

9. Setyowati W. T., Nisa F. C. Formulasi Biskuit Tinggi Serat (Kajian Proporsi Bekatul Jagung : Tepung Terigu dan Penambahan Baking Powder). Jurnal Pangan dan Agroindustri Vol. 2, No.3, p.224-231; 2014.

10. Engganeyski. J. C., Simon B. W. Studi Daya Cerna (In Vitro) Biskuit Tepung Ubi Jalar Kuning dan Tepung Jagung Germinasi. Jurnal Pangan dan Agroindustri Vol. 4, No.1, p.391-399; 2016.

11. Pete S. F. Uji Daya Terima dan Nilai Gizi Biskuit yang Dimodifikasi dengan Tepung Kacang Merah. Jurnal Industri dan Pangan, Vol. 2, No. 6; 2013.

12. Evanuarini H., Nurliyani, Indratiningsih, Hastuti P. Characteristic of Low fat Mayonnaise Containing Porang Flour as Stabilizer. Pakistan Journal of Nutrition 14 (7): 392-395 ISSN 16805194; 2015.

13. Lala F. H., Susilo B., Komar N. Uji Karakteristik Mie Instan Berbahan-Baku Tepung Terigu dengan Substitusi Mocaf. Jurnal Bioproses Komoditas Tropis Vol. 1 No.2; 2013.

14. Kalukiningrum S. Pengembangan Produk Cake dengan Substitusi Tepung Mocaf [Skripsi]. Yogyakarta: Universitas Negeri Yogyakarta; 2012.

15. Gallagher M.L., The Nutrients and Their Metabolism. In: Mahan LK, Escott-Stump S. Krause's Food and Nutrition Therapy. $12^{\text {th }}$ ed. Canada: Saunders Elsevier, p.47, 64, 71-73; 2008.

16. Guy G. D. B. Risk Factor and Prevention of Cardiovascular Disease: A Review. Dialogues in Cardiovascular Medicine, Vol. 13 No. 2; 2008. 
17. Murwani S., Ali M., Muliartha K. Diet Aterogenik pada Tikus Putih (Rattus novergicus strain Wistar) sebagai Model Hewan Aterosklerosis. Jurnal Kedokteran Brawijaya, Vol. XXII, No. 1, 2006.

18. Dhingra D., Michael M., Rajput H. Dietary Fibre in Foods: A Review. J Food Sci Technol 49(3):255-266; 2012.

19. Desminarti S. Kajian Serat Pangan dan Antioksidan Alami Beberaoa Jenis Sayuran serta Daya Serap dan Retensi Antioksidan pada Tikus Percobaan [Tesis]. Bogor: Institur Pertanian Bogor; 2001.

20. Haryani K., Hargono. Proses Pengolahan Iles-Iles (Amorphophallus sp.) menjadi Glukomannan sebagai Gelling Agent Pengganti Boraks. Momentum Vol. 4, No. 2; 2008.

21. Sugiarto M. Efek Terapi Yogurt Susu Kambing Terhadap Ekspresi Inducible Nitric Oxyde dan Kadar Malonaldehida (MDA) Pada Aorta Hewan Model Tikus (Rattus norvegicus) Hiperkolesterolemia. [Skripsi]. Malang: Universitas Brawijaya; 2012.

22. Santoso A. Serat Pangan (Dietary Fiber) dan Manfaatnya bagi Kesehatan. Magistra No. 75 Th. XXIII; 2011.

23. Sartika R. A. D. Pengaruh Asam Lemak Jenuh, Tidak Jenuh dan Asam Lemak Trans terhadap Kesehatan. Jurnal Kesehatan Masyarakat Nasional Vol. 2, No. 4; 2008.

24. Susanti N. Suplementasi Tepung Porang (Amorphophallus muelleri Blume) sebagai Nutraceutical dalam Manajemen Diabetes Mellitus Tipe 2. El-Hayah Vol. 5, No. 1; 2014.

25. Nugraheni B., Cahyani I. M., Herlyanti K. Efek Pemberian Glukomanan Umbi Porang (Amorphophallus oncophyllus Prain ex Hook. F.) terhadap Kadar Kolesterol Total Darah Tikus yang Diberi Diet Tinggi Lemak. Jurnal Ilmu Farmasi dan Farmasi Klinik Vol. 11, No. 2; 2014.

26. Mervina, Kusharto C. M., Marliyati S. A. Formulasi Biskuit dengan Substitusi Tepung Ikan Lele Dumbo (Clarias gariepinus) dan Isolat Protein Kedelai (Glycine max) sebagai Makanan Potensial untuk Anak Balita Gizi Kurang. J. Teknol. dan Industri Pangan, Vol. XXIII No. 1; 2013.

27. Dewan Standardisasi Nasional. SNI 01-29731992; Biskuit. Dewan Standardisasi Nasional. 1992.

28. Lasmini A. Y. Pemanfaatan Tepung Iles-Iles Kuning (Amorphophallus onchophyllus) sebagai Sumber Serat pada Pembuatan Cookies Berserat Tinggi. [Skripsi]. Bogor: Institut Pertanian Bogor; 2002.
29. Gracia C. C. L., Sugiyono, Haryanto B. Kajian Formulasi Biskuit Jagung dalam Rangka Substitusi Tepung Terigu. J. Teknol. dan Industri Pangan, Vol. XX, No. 1; 2009. 